\title{
熱を受けるコンクリート埋め込みボルトの引抜きに関する実験 \\ EXPERIMENTAL STUDY ON PULL-OUT BEHAVIOR OF CAST-IN-PLACE ANCHOR BOLT IN CONCRETE UNDER HIGH TEMPERATURE
}

\author{
橋本 純*, 瀧口克已** \\ Jun HASHIMOTO and Katsuki TAKIGUCHI
}

\begin{abstract}
This paper presents experimental study on the behavior of cast-in-place anchor bolt embedded in concrete subjected to high temperatures up to $500^{\circ} \mathrm{C}$, with the specific objectives to obtain basic experimental data and to examine the response of cast-in-place anchor bolts to high temperature exposure. The specimens with two kinds of embedment depth of anchor bolt, $3 \mathrm{~cm}$ and $5 \mathrm{~cm}$, are prepared. Under constant tensile load applied to the anchor bolt, the specimen is heated and the relation between the pull-out strength and temperature at fracture is examined. As to the process of heating, two different rate of temperature elevation, $10^{\circ} \mathrm{C} / \mathrm{min}$. and $0.75^{\circ} \mathrm{C} / \mathrm{min}$, were prepared. As a result of the test, regardless of different parameters studied in this experiment, comparison with the earlier research results indicated that identical ratio of pull-out strength of anchor bolt was obtained when the same temperature of concrete surrounding the bolt head was applied.
\end{abstract}

Keywords : Concrete, Anchor bolt, high temperature, pull-out strength, embedment depth コンクリート, アンカーボルト, 高温, 引抜き耐力, 埋め込み梁さ

\section{1. 序}

現在コンクリート構造物はいたるところに存在している。火災や 事故によって高温にさらされる可能性があり, 安全性を確保するに は高温加熱を受けたコンクリート構造物の挙動が問題となる。加熱 によってコンクリートの強度特性や熱特性は変化すると報告されて

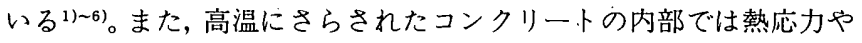
熱膨張, 含水分の蒸発による水蒸気圧などが生じている718)。コンク リートの含水状態によっては局部的な爆裂が起こるという報告もあ る ${ }^{9110)}$ 。したがって, コンクリート構造物が短期あるいは長期的に高 温を受けた場合, その耐力の低下が懸念される。しかし, 上記に挙 げた様々な要因が複雑に関係してくるため高温下のコンクリートの 挙動に関する情報はいまだ十分に得られてなく，コンクリート構造 物の熱挙動を把握することは困難である。したがって，コンクリー 卜構造物に高温と外力を同時に作用させた場合の挙動を実験によっ て把握することは有効であると考えられる。

筆者らは，コンクリート構造物としてコンクリートに埋め込まれ たアンカーボルトに着目した。アンカーボルトは構造躯体コンク リートへの機器類の固定などを目的として，その引抜き耐力にも期 待して多く用いられている。アンカーボルトはコンクリートの表面 に埋め込まれているため，コンクリートが加熱された場合引抜き耐 力に熱の影響が顕著に表れると予想される。前報11において埋め込 み梁さ $3 \mathrm{~cm}$ としてコンクリートに埋め込んだアンカーボルトの $500^{\circ} \mathrm{C}$ までの加熱下における引抜き実験及び結果を報告した。 $500^{\circ} \mathrm{C}$ までの高温下で引抜き耐力は最大 $20 \%$ まで低下した。また $500{ }^{\circ} \mathrm{C} に$ 加
熱した後常温に泠却した場含，アンカーボルトの引抜き耐力は常温 での耐力の $50 \%$ を示した。しかし，前報で得られた結果はボルトの 埋め込み深さや加熱経路が限定されている。アンカーボルトの引抜 き耐力は埋め込み深さに大きく依存している。また, 加熱経路によっ てコンクリート内部の温度差が変化するため, 埋め込み深さや加熱 経路を変えて実験データを蓄積することは，高温下でのアンカーボ ルトの引抜き破壊の要因を把握するために必要である。

本研究では前報で報告した埋め込み梁さ $3 \mathrm{~cm}$ のアンカーボルト の加熱下での引抜き実験を加熱時の温度の上昇速度を変えて行うと ともに, 埋め込み深さ $5 \mathrm{~cm}$ として同様の引抜き実験を行う。前報お よび本報で得られた実験結果より埋め込み梁さの違うアンカーボル トの高温下での引拢き耐力を比較検討し, 高温加熱とアンカーボル トの引抜き耐力の関係を決定する要因について検討することを目的 とする。

\section{2. 実験概要 \\ 2.1 試験体}

表 1 に試験体リスト，表 2 に試験体に使用した鋼材の力学特性を 示す。また，コンクリートの調合を表 3 に，使用骨材の品質を表 4 に示す。試験体数はアンカーボルトの埋め込み哚さ $3 \mathrm{~cm}$ とした試験 体（ABT-S）23体，5cm とした試験体（ABT-L）20体である。本 実験では, コンクリートと高温の関係を調べるために，アンカーボ ルトが引張力を受けた場合の破壊形式としてコンクリートのコーン 状破壊を想定して試験体を設計している。しかし，加熱を伴った試
* 東京工業大学 大学院生

** 東京工業大学 教授・工博
Graduate Student, Tokyo Institute of Technology

Prof., Tokyo Institute of Technology, Dr. Eng. 
表 1 試験体リスト

\begin{tabular}{|c|c|c|c|c|c|}
\hline \multirow{2}{*}{$\begin{array}{c}\text { 試験体 } \\
\text { 名 }\end{array}$} & \multirow{2}{*}{$\begin{array}{c}\text { 試験体 } \\
\text { 数 }\end{array}$} & \multirow[b]{2}{*}{$b \times D \times h(m m)$} & \multirow{2}{*}{$\begin{array}{l}\text { アンカーボルト } \\
\text { 埋め込み泳さ }\end{array}$} & \multicolumn{2}{|c|}{ コンクリート } \\
\hline & & & & $\begin{array}{l}\text { 圧縮強度 } \\
\left(\mathrm{N} / \mathrm{mm}^{2}\right)\end{array}$ & $\begin{array}{c}\text { 引張強度 } \\
\left(\mathrm{N} / \mathrm{mm}^{2}\right)\end{array}$ \\
\hline$A B T-S$ & 23 & $240 \times 240 \times 120$ & $\begin{array}{c}\mathrm{M} 12 \times 80 \\
30 \mathrm{~mm}\end{array}$ & 46.2 & 3.75 \\
\hline$A B T-L$ & 20 & $500 \times 500 \times 180$ & $\begin{array}{c}M 16 \times 120 \\
50 \mathrm{~mm}\end{array}$ & 38.6 & 3.31 \\
\hline
\end{tabular}

表 2 鋼材の力学特性

\begin{tabular}{c|c|c|c}
\hline & $\begin{array}{c}\text { 降伏点 } \\
\left(\mathrm{N} / \mathrm{mm}^{2}\right)\end{array}$ & $\begin{array}{c}\text { 引張強さ } \\
\left(\mathrm{N} / \mathrm{mm}^{2}\right)\end{array}$ & $\begin{array}{c}\text { ヤング係数 } \\
\left(\times 10^{5} \mathrm{~N} / \mathrm{mm}^{2}\right)\end{array}$ \\
\hline アンカーボルト M12 & 378 & 446 & 1.91 \\
\hline アンカーボルト M16 & 361 & 469 & 2.02 \\
\hline 翼形鉄箉 D13 & 358 & 528 & 1.93 \\
\hline
\end{tabular}

表 3 コンクリートの調合

\begin{tabular}{|c|c|c|c|c|c|c|c|}
\hline \multirow[b]{2}{*}{ 試験体 } & \multirow{2}{*}{$\begin{array}{c}\text { 水セxント比 } \\
(\%)\end{array}$} & \multicolumn{6}{|c|}{ 頙量 $\left(\mathrm{kg} / \mathrm{m}^{3}\right)$} \\
\hline & & 水 & セメント & 紐骨材(1) & 細骨材(2) & 粗骨材 & $\begin{array}{c}\text { 混和剂 } \\
\text { (ポゾリス }\end{array}$ \\
\hline$A B T-S$ & 50.5 & 183 & 363 & 548 & 235 & 953 & 0.907 \\
\hline$A B T-L$ & 52.5 & 185 & 353 & 553 & 237 & 944 & 0.882 \\
\hline
\end{tabular}

表 4 使用骨材

\begin{tabular}{|c|c|c|c|c|c|c|}
\hline 試験体 & & 骨材の種類 & $\begin{array}{c}\begin{array}{c}\text { 最大寸法 } \\
(\mathrm{mm})\end{array} \\
\end{array}$ & 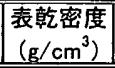 & 粗僦率 & $\begin{array}{c}\text { 吸水率 } \\
(\%)\end{array}$ \\
\hline \multirow{3}{*}{$\mathrm{ABT}-\mathrm{S}$} & 細骨材(1) & 千葉県君津産砂 & 5 & 2.59 & 2.39 & 2.45 \\
\hline & 細骨材(2) & 東京都青梅産䂶砂 & 5 & 2.61 & 3.05 & 1.13 \\
\hline & 粗骨材 & 菒京都奥多摩産砕石 & 20 & 2.67 & 6.59 & 0.44 \\
\hline \multirow{3}{*}{$A B T-L$} & 細骨材(1) & 千葉県君津産砂 & 5 & 2.59 & 2.39 & 2.33 \\
\hline & 細骨材(2) & 東京都留梅産砕砂 & 5 & 2.61 & 3.07 & 1.16 \\
\hline & 粗骨材 & 東京都舆多鹰産砕石 & 20 & 2.66 & 6.62 & 0.61 \\
\hline
\end{tabular}

験であることを考慮して，アンカーボルトとして使用した M12及び M16の材料試験を行った。アンカーボルトの力学特性は実験に使用 したボルトと同一のボルトから取り出した供試体により得られた。 圧縮強度及び引張強度は，試験体と同一バッチのコンクリートで作 製したシリンダー供試体の圧縮試験及び割裂試験により得られた。 試験体のコンクリート打設は試験体下面から行った。試験体及びシ リンダーの養生は，打設後試験直前まで型枠内で湿潤養生とし，実 験当日に脱型を行った。

アンカーボルトの埋め込み深さ $3 \mathrm{~cm}$ の試験体は前報と同様であ る。各試験体ともに $b \times D \times h=240 \times 240 \times 120 \mathrm{~mm}$ であり, M12×80 をアンカーボルトとして使用した。アンカーボルトの埋め込み染さ $5 \mathrm{~cm}$ とした試験体を罒 1 に示す。各試験体ともに $b \times D \times h=500 \times$ $500 \times 180 \mathrm{~mm}$ である。図 2 にアンカーボルト埋め込み困を示す。アン カ一ボルトとして M16を使用し, 試験体中央に埋め込み樑さ $5 \mathrm{~cm}$ として埋め込んだ。試験体の曲げ破壊防止のためにD13を 4 本使用 した。四角ナット及び鋼管は載荷装置に固定するために埋め込んだ。 全20体中 5 体に試験体内部温度を測定するため熱電対を計 13 ヶ所埋 め込んだ。温度测定点はアンカーボルト部分に 2 ケ所，コンクリー 卜部分 $10 ヶ$ 所，および鉄筋部分に 1 ケ所とした。ボルトおよび鉄筋 の温度測定にセラミックファイバー被覆熱電対を，コンクリートの

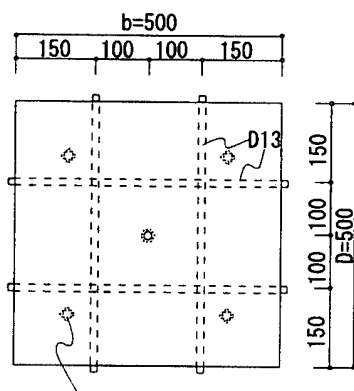

四角ナット

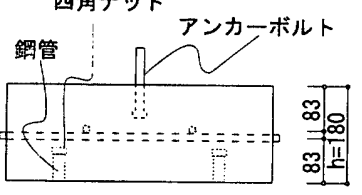

$\frac{100+150+150+100}{500}$

熟䖞对なし

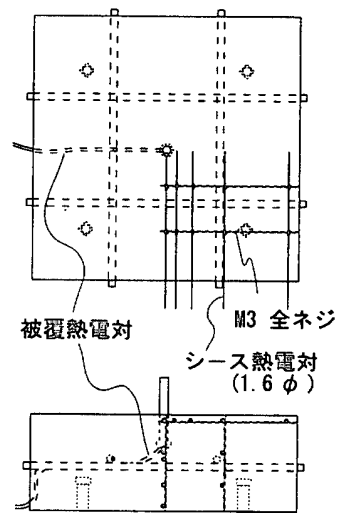

熱電対あり

(・: 温度測定点)

図 1 試験体 (ABT-L)

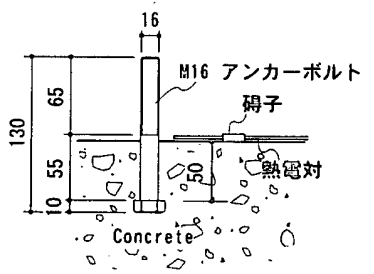

図 2 アンカーボルト埋め込み詳細

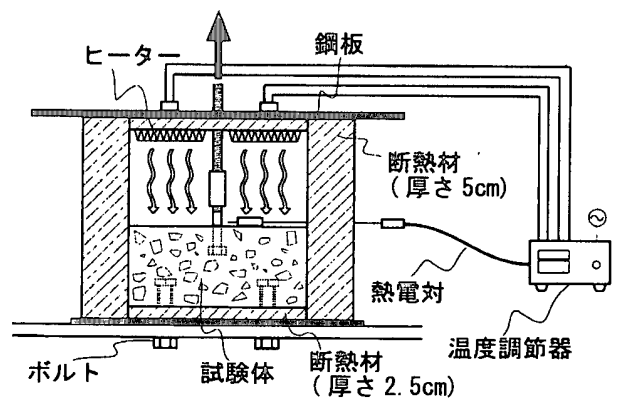

园 3 載荷·加熱概念区

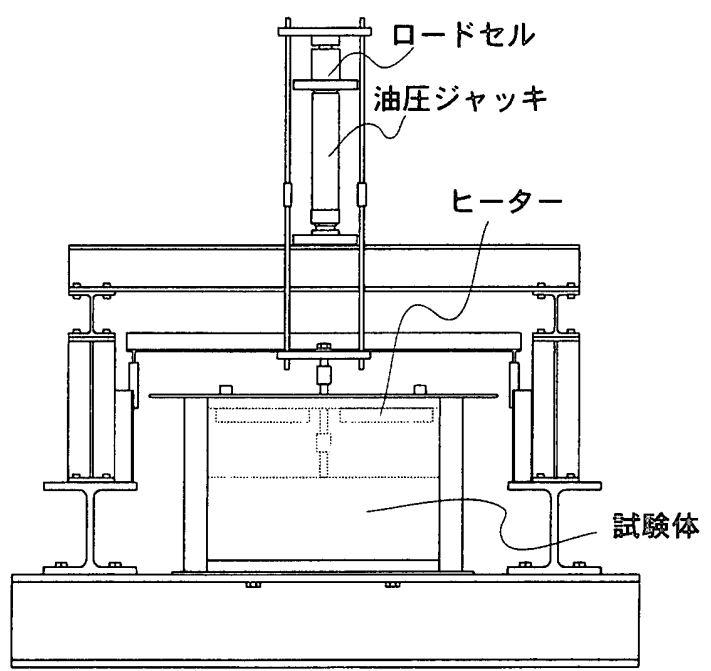

図 4 載荷装置（ABT-L） 
温度測定に外径 $1.6 \mathrm{~mm}$ のシース熱電対を使用した。またこれらの 熱電対を試験体内部に固定するためにM3全ねじを用いた。

\section{2 載荷装置}

$\mathrm{ABT}-\mathrm{S} 及 ひ ゙ \mathrm{ABT}-\mathrm{L} の$ 載荷に異なる載荷装置を用いた。しかし， 図 3 の載荷・加熱概念図に示すようにアンカーボルトに鉛直方向に 引張力を加え, 試験体上面から加熱を行うという実験のシステムは 同じである。

ABT-Sの載荷装置は前報と同様である。アンカーボルトに接続 した加力ビームに鏵を吊るすことによって，アンカーボルトに引張 力を作用させた。ABT-Lの載荷に用いた載荷装置図を図 4 に示す。 加力には $5 \mathrm{t}$ 油圧ジャッキを用いた。荷重增加時は静的単調引張載荷 とし, 一定引張荷重を与える場合にはジャッキの微調整により荷重 の低下を防いだ。アンカーボルトの引張荷重の大きさは油圧ジャッ キ上部に取り付けたロードセルによって測定した。試験体は下から 4 本のボルトによって載荷装置に固定し反力を取っている。加熱は ニクロム線を用いた電気ヒーターにて, 図 3 に示すようにアンカー ボルトを埋め込んだ試験体上面から行った。加熱面の空気の温度(以 下表面温度とする）を熱電対により測定し，この温度により加熱時 の温度上昇速度（以下加熱速度とする）と最高温度を制御した。電

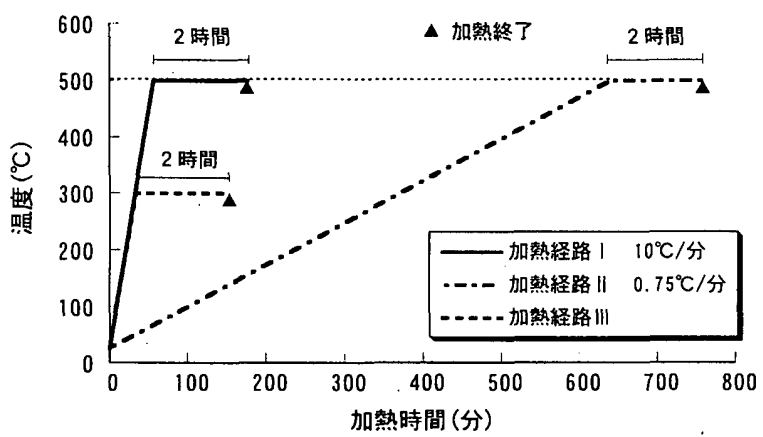

図 5 加熱経路

表 5 常温での引抜き耐力

\begin{tabular}{c|c|c}
\hline \multirow{2}{*}{ 試駚体名 } & $\begin{array}{c}\text { 常温での引抜き耐力 } \\
(\mathrm{kN})\end{array}$ & \multirow{2}{*}{$\mathrm{P}_{0}(\mathrm{kN})$} \\
\hline \multirow{3}{*}{$\mathrm{ABT}-\mathrm{S}$} & 16.3 & \multirow{2}{*}{17.3} \\
\cline { 2 - 2 } & 17.8 & \\
\cline { 2 - 2 } & 17.7 & \multirow{2}{*}{37.6} \\
\hline \multirow{3}{*}{$\mathrm{ABT}-\mathrm{L}$} & 36.3 & \\
\cline { 2 - 2 } & 37.0 & \\
\cline { 2 - 2 } & 39.6 & \\
\hline
\end{tabular}

気ヒーターの性能は ABT-S の実験で用いた電気ヒーターと同様に 加熱速度を制御しない場合に毎分約 $10^{\circ} \mathrm{C}$ となるように設計してい る。試験体周囲およびヒーター外部には断熱材を取り付け，加熱時 の熱損失を防止した。

\section{3 実験方法}

加熱経路を図 5 に示す。加熱経路 I は加熱速度を制御せずにヒー ターの性能に任せた毎分約 $10^{\circ} \mathrm{C}$ として表面温度が $500^{\circ} \mathrm{C}$ に達するま で加熱を行う。 $500^{\circ} \mathrm{C}$ に達した後は 2 時間 $500^{\circ} \mathrm{C}$ を保ち加熱終了とす る。加熱経路 II は, 加熱速度を毎分 $0.75^{\circ} \mathrm{C}$ とし $500^{\circ} \mathrm{C}$ まで加熱を行い, $500^{\circ} \mathrm{C}$ 到達後, 加熱経路 I 同様 2 時間温度を保つ。加熱経路IIIは, 加 熱速度毎分約 $10^{\circ} \mathrm{C}$ で $300^{\circ} \mathrm{C}$ まで加熱し 2 時間 $300^{\circ} \mathrm{C}$ を保ち加熱終了と する。各加熱経路ともに加熱終了後は試験体を気中に放置すること で常温まで泠却する。

ABT-S，ABT-L ともに常温における引抜き試験を行い，常温で の引抜き耐力の平均值 $P_{0}$ を求めた。 $\mathrm{ABT}-\mathrm{S}$ は前報で報告した加熱 速度毎分 $10^{\circ} \mathrm{C}$ を用いた実験結果との比較のために，加熱経路 II を用 いて一定引張力下での加熱試験を行った。アンカーボルトに一定引 張荷重 $P$ を作用させ試験体の加熱を行い，試験体が破壊した時点で 実験終了とした。一定引張荷重 $P$ は $P_{0}$ の $40 \%$ から $80 \%$ の範囲とし た。加熱終了までに破壊しなかった試験体は，冷却後引張荷重を増 加することで，加熱後の引抜き耐力を調べた。

ABT-Lは, ABT-Sの実験結果と比較し埋め込み深さの違いに よる影響を調べるため，加熱経路 I 及びIIを用いて $P_{0}$ の $20 \%$ から $80 \%$ の範囲で一定引張荷重をアンカーボルトに作用させ加熱試験を 行った。加熱中に破壊しなかった試験体については，加熱後の引抜

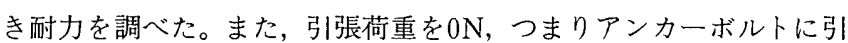
張荷重を作用させない状態で加熱経路IIIを用いて加熱・冷却を行 い, 加熱後にアンカーボルトの引抜き試験を行い, 加熱後の残存引 抜き耐力を調べた。

\section{3. 実験結果}

表 5 に常温での引抜き耐力とその平均值 $P_{0}$ を示す。アンカーボ ルト埋め込み染さ $5 \mathrm{~cm}$ の試験体はコーン状破壊であったのに対し, 埋め込み深さ $3 \mathrm{~cm}$ の試験体はアンカーボルトから放射状にひび割 れが生じアンカーボルトが引抜けている。一定引張荷重 $P$ を常温で の引抜き耐力の $60 \%$ を一定引張荷重としてアンカーボルトに作用さ せて行った加熱試験の結果を図 6 に示す。加熱速度毎分 $10^{\circ} \mathrm{C}$ とた 場合, 埋め込み媣さ $5 \mathrm{~cm}$ のアンカーボルトは表面温度 $368^{\circ} \mathrm{C} て ゙$ 破壤

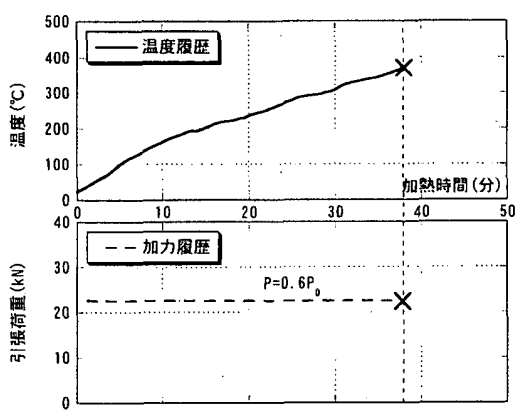

(a) $\mathrm{ABT}-\mathrm{L}$ (加熱経路 $\mathrm{I}$ )

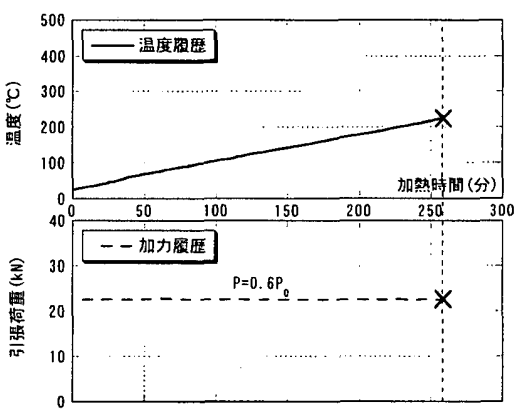

(b) $\mathrm{ABT}-\mathrm{L}$ (加熱経路 II)

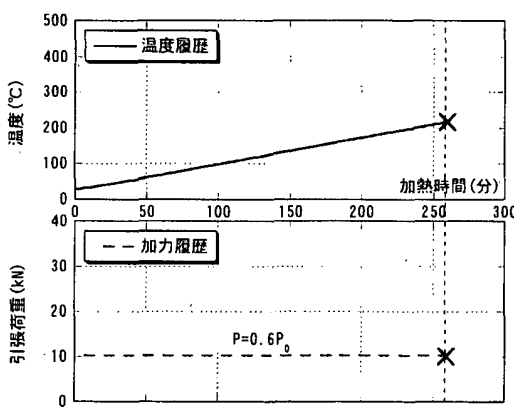

(c) ABT-S(加熱経路II)，

図 6 一定引張力下での加熱試験結果 


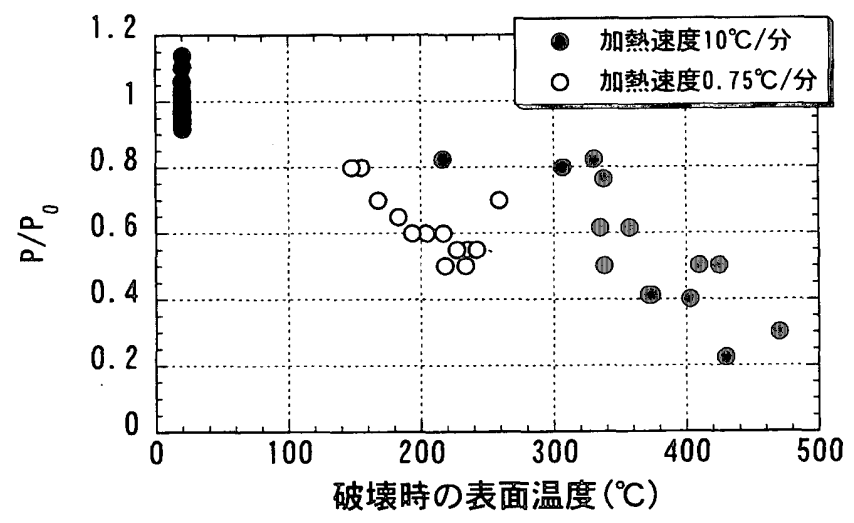

(a) ABT-S

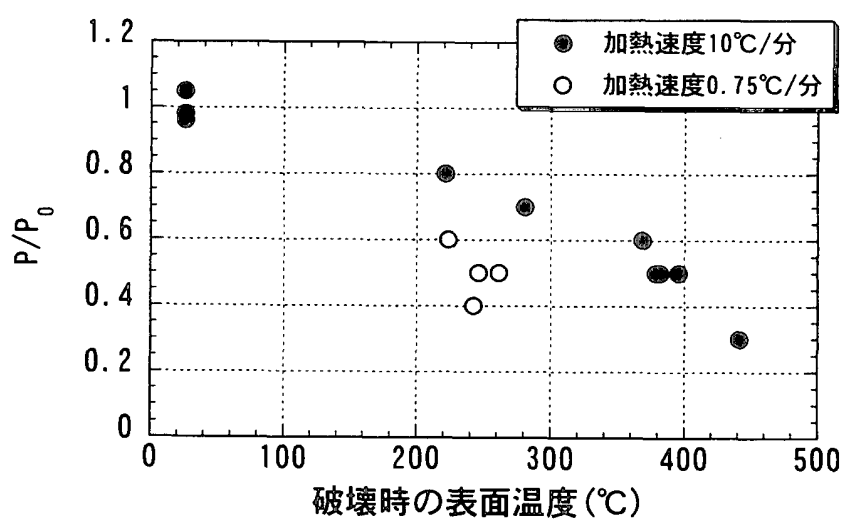

(b) $\mathrm{ABT}-\mathrm{L}$

図 7 破壞時表面温度と引抜き耐力の関係

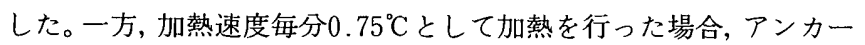

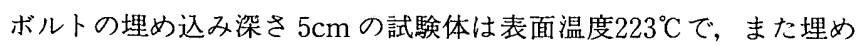

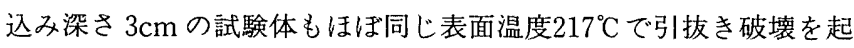
こした。図 7 に加熱中に破壊した試験体の破壊時の表面温度とアン カーボルトの引抜き耐力の関係を示方。縦軸は常温での引抜き耐力 で除している。アンカーボルト埋め込み深さ $3 \mathrm{~cm}$ の実験結果につい ては前報で報告した結果と合わせて示している。異なる埋め込み哚 さにも関わらず, 破壊時の表面温度と引抜き耐力の関係はほぼ一致 した。加熱温度が高いほど引抜き耐力の低下が大きく，加熱速度毎 分 $10^{\circ} \mathrm{C}$ の場合表面温度が $500^{\circ} \mathrm{C}$ に到達するまでに常温での耐力の約 $20 \%$ だ低下した。破壊時, 埋め込み深さ $3 \mathrm{~cm}, 5 \mathrm{~cm}$ の試験体共に
加熱面のコンクリートが爆発音を伴って粉砕し，コンクリート片が 飛び散った。一方，アンカーボルトに同じ引張荷重が作用している 時, 加熱速度が速い場合と比較して, 加熱速度が遅い場合は $100^{\circ} \mathrm{C}$ 程 低い温度でアンカーボルトの引抜き破壞が起こった。この時, 常温 時と似た破壊状況であったが，加熱面は大きなコンクリート片と なって破壊した。加熱速度を毎分 $0.75^{\circ} \mathrm{C}$ とした場合, 表面温度 $250^{\circ} \mathrm{C}$ 付近で常温での耐力の $40 \sim 50 \%$ まで低下した。しかし, 引張荷重が 常温での引抜き耐力の $40 \%$ 以下の場合, $500^{\circ} \mathrm{C}$ まで加熱してもアン カーボルトが引抜けることはなかった。

図 8 に加熱後常温まで泠却し行った引抜き試験の結果を示す。埋 め込み深さ $3 \mathrm{~cm}$ の試験体 2 体を用いて, 一定引張荷重を常温での引

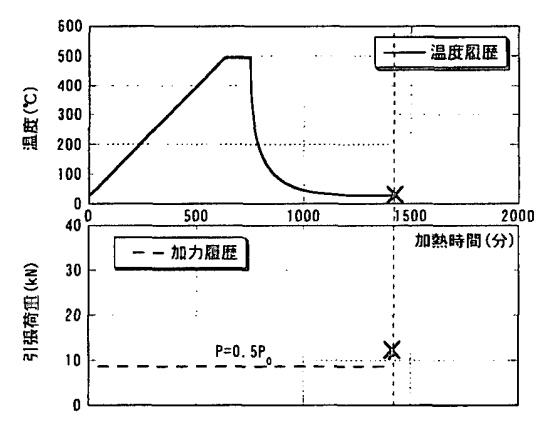

(a) $\mathrm{ABT}-\mathrm{S}($ 加熱経路 II)

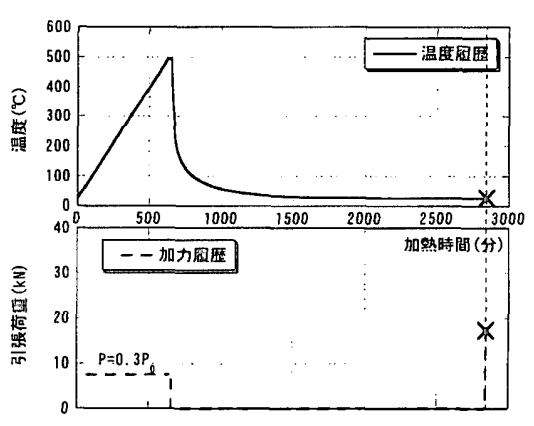

(b) ABT-L (加熱経路 II)

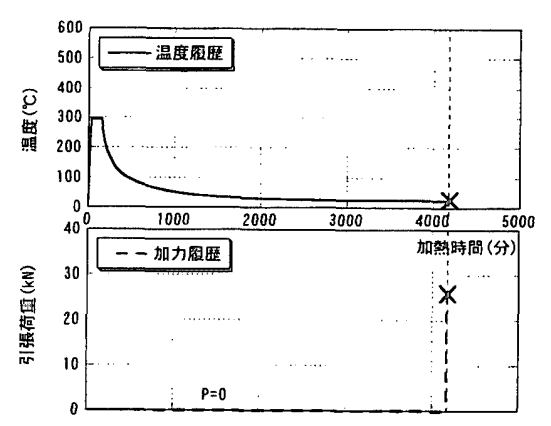

(c) ABT-L (加熱経路III)

図 8 加熱後の引抜き試験結果

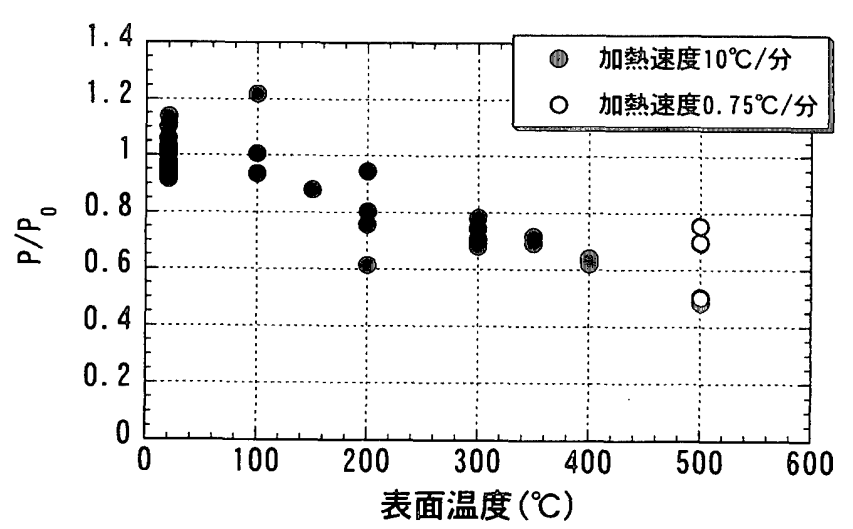

(a) ABT-S

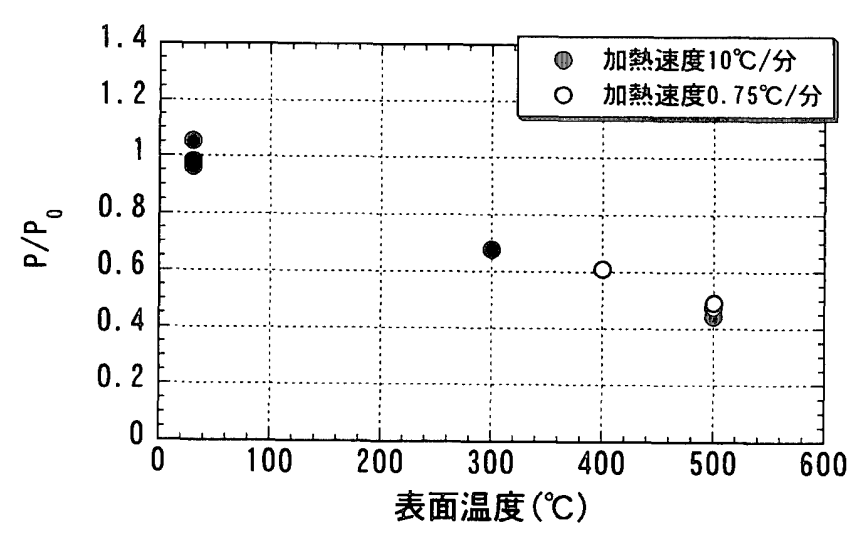

(b) $\mathrm{ABT}-\mathrm{L}$

図 9 加熱冷却後の引抜き耐力と加熱温度の関係 
抜き耐力の $50 \%$, 加熱速度毎分 $0.75^{\circ} \mathrm{C}$ とて $500^{\circ} \mathrm{C}$ までの加熱試験を 行った。前報において同様の条件下で行った実験では表面温度 $220^{\circ} \mathrm{C}$ 付近で試験体は破壊したが, 本実験では加熱終了まで引抜き破壞が 起きなかった。1 体は冷却途中でアンカーボルトが引抜け, 他 1 本 の冷却後の残存引抜き耐力は $12.0 \mathrm{kN}\left(0.7 P_{0}\right)$ であった。埋め込み 梁さ $5 \mathrm{~cm}$ の試験体で一定引張荷重を常温での引抜き耐力の $30 \%$, 加 熱速度毎分 $0.75^{\circ} \mathrm{C}$ して加熱試験を行った場合も同様に加熱中に破 壊しなかった。この試験体において表面温度が $500^{\circ} \mathrm{C}$ 達した時点で 加熱終了とし，また冷却時に除荷した。冷却後の残存引抜き耐力は $18.4 \mathrm{kN}\left(0.5 P_{0}\right)$ となり, 加熱速度毎分 $10^{\circ} \mathrm{C}$ として $500^{\circ} \mathrm{C}$ まで加熱を ・行い冷却した場合の残存引抜き酎力と同等の值を示した。また, 加 熱速度毎分 $10^{\circ} \mathrm{C}$ で $300^{\circ} \mathrm{C}$ まで加熱, 冷却を行った埋め込み深さ $5 \mathrm{~cm}$ の試験体の引抜き耐力は $25.5 \mathrm{kN}$ であった。加熱後常温まで泠却し 引拔き試験を行った試験体の加熱時の最高表面温度と引抜き耐力の 関係を図 9 に示す。埋め込み染さに関係なく, 加熱後の引抜き耐力 と加熱温度の関係はほぼ一致している。加熱速度毎分 $10^{\circ} \mathrm{C} の$ 場合, 加熱後のアンカーボルトの引拔き耐力は加熱温度に比例して低下 し, $500^{\circ} \mathrm{C}$ の加熱後の引抜き耐力は常温での耐力の約 $50 \%$ となった。 しかし, 加熱速度毎分 $0.75^{\circ} \mathrm{C} て ゙ 500^{\circ} \mathrm{C}$ まで加熱し冷却した場合の引抜
き耐力は埋め込み梁さ $5 \mathrm{~cm}$ では常温での耐力の約 $50 \%$, 埋め込み深 さ $3 \mathrm{~cm}$ では約 $70 \%$ と違いが見られた。

ABT-Lについて加熱時の試験体内部の温度履歴を図10に示す。 加熱速度毎分 $10^{\circ} \mathrm{C}$ 及び毎分 $0.75^{\circ} \mathrm{C}$ にいて試験体下部のコンクリー ト部分が $100^{\circ} \mathrm{C}$ を超えると温度上昇が暫く停滞している。また，同じ 水平面上にあるコンクリート温度を比較すると, ボルトの下に位置 する測定点 $3 ， 5$ はそれぞれ測定点 $8 ， 9$ より若干高くなっている。 これらは，ABT-Sにも同様の傾向が見られた。

\section{4. 考察}

\section{1 アンカーボルトの埋め込み深さの違いに関する検討}

本実験ではアンカーボルトを埋め込んだ試験体上面から加熱を 行っており，試験体内部には鉛直方向に温度分布が発生するため, 加熱温度と引抜き耐力の関係にアンカーボルトの埋め込み梁さが影 響すると予想された。しかし，埋め込み深さ $3 \mathrm{~cm}$ 及び $5 \mathrm{~cm}$ の実験結 果を比較すると, 加熱温度とアンカーボルトの引抜き耐力の関係に 大差はなかった。

図11に ABT-LおよびABT-Sについて破壊時の試験体内部の 温度分布を示す。これらの試験体内部温度は, 熱電対を埋め込んだ

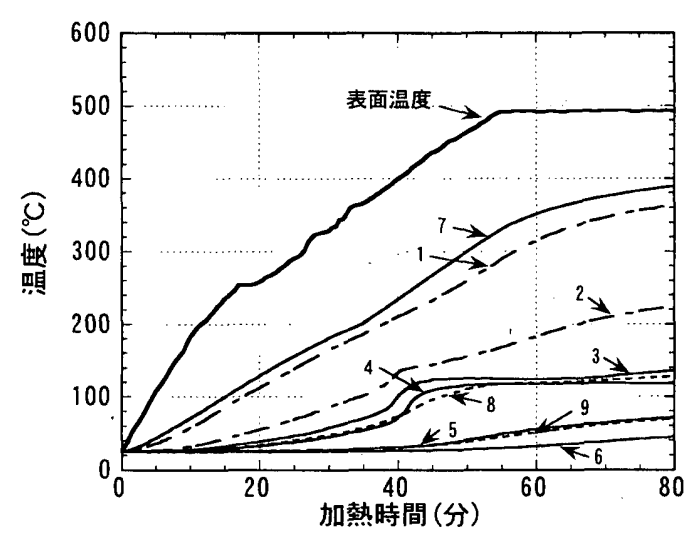

(a) 加熱経路 I

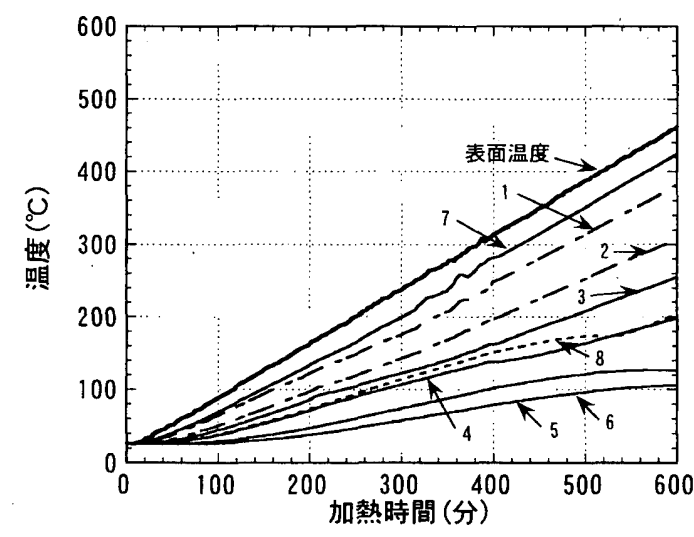

(b) 加熱経路 II

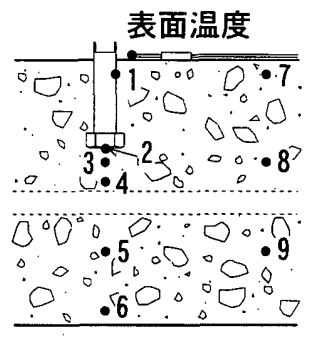

図10加熱時の試験体内部温度䧗歴

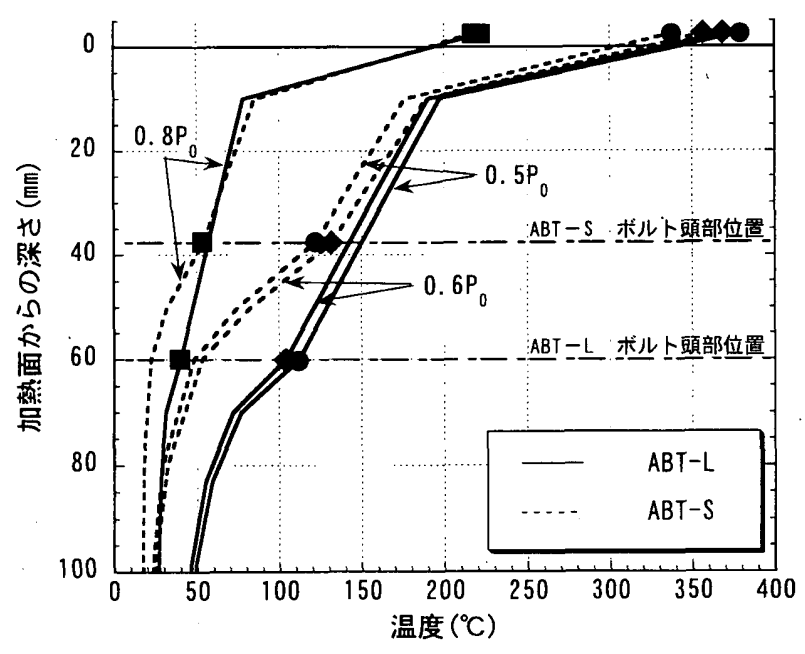

(a) 加熱経路 I

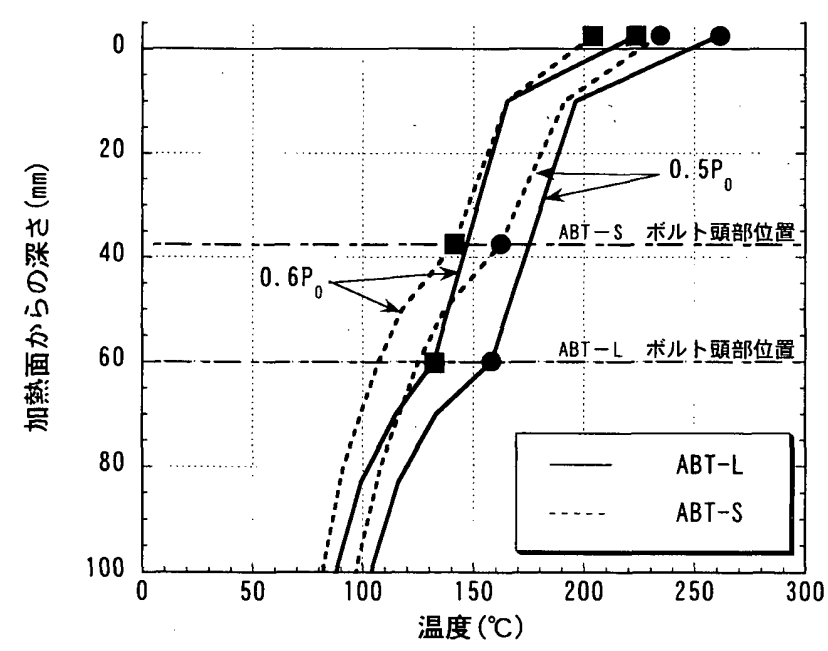

(b) 加熱経路 II

図11 破壞時の試豎体内部温度分布 


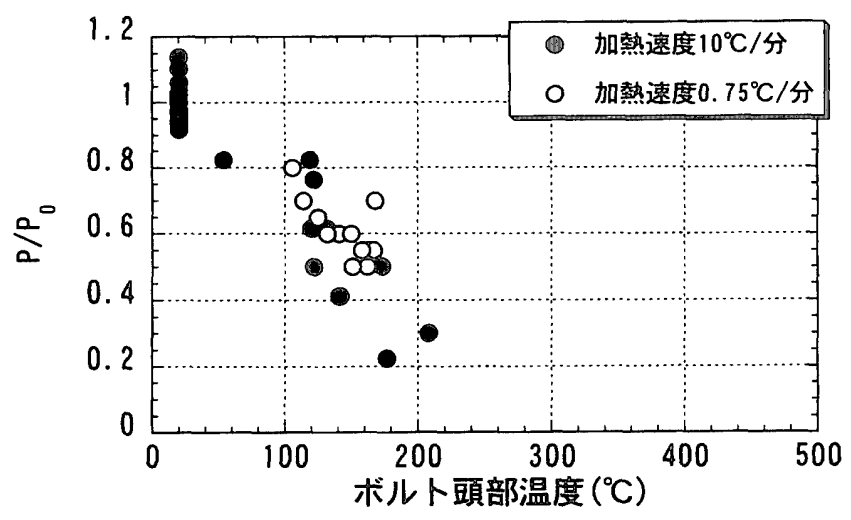

(a) $\mathrm{ABT}-\mathrm{S}$

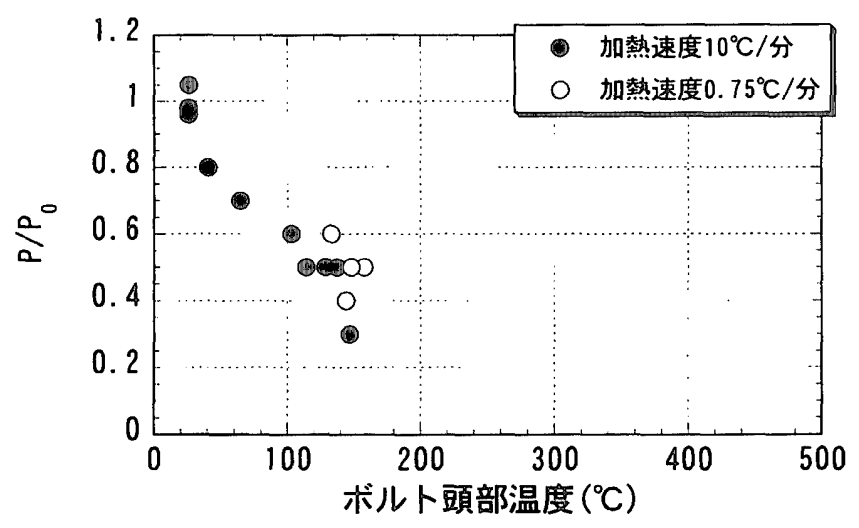

(b) ABT-L

図12 ボルト頭部温度と引抜き耐力の関保

試験体で行った温度測定の結果より求めたものである。ボルトの頭 部より梁い位置にあるコンクリート部分では温度が著しく低下して いる。これはボルトとコンクリートでは熱伝導率が大きく異なり， ボルトはよく熱を伝えるのに対し，コンクリートは熱を伝えにくい ためである。また, 図10の試験体内部の温度履歴において, 測定点 3 が測定点 8 より若干高い温度を示していることも, ボルトの熱伝 導率が大きいためと考えられる。

$3 \mathrm{~cm}, 5 \mathrm{~cm}$ の埋め込み深巳において加熱速度毎分 $10^{\circ} \mathrm{C}$ の時, 破壊時 の表面温度が同じであった。また試験体内部温度を比較すると, 破 壊時のボルト頭部も同じ温度であった。本研究ではアンカーボルト が引張力を受けた場合の破壊形式としてコンクリートのコーン状破 壊を想定して試験体を設計しているため, アンカーボルトの埋め込 み梁さは $3 \mathrm{~cm}$ 及び $5 \mathrm{~cm}$ と比較的浅く設定している。これらのこと から, 同じ加熱経路で加熱を行った場合埋め込み染さが $3 \mathrm{~cm}, 5 \mathrm{~cm}$ と異なっても加熱の初期段階ではボルト頭部温度に差があまり生じ なかった。

加熱速度が遅い場合にも引抜き破壊時のボルト頭部温度はほぼ同 じ温度となっている。加熱に時間をかける場合，熱伝導率の違いに よる影響が少ない。そのため, 埋め込み深さ $5 \mathrm{~cm} の$ 試験体が埋め込 み梁さ $3 \mathrm{~cm}$ の試験体に比べてわずかであるが破壊時の表面温度は 高い温度に達している。

アンカーボルトに引張力を加之た場合，コンクリート中を伝わる 力として，ボルト頭部から試験体表面へと向かう力とボルト埋め込 み方向に対して垂直な面上において円状に作用する力がある。ボル トの埋め込み深さ $3 \mathrm{~cm}, 5 \mathrm{~cm}$ として行った試験結果より, 表面温度 が同じ時にはボルト頭部温度もほぼ同じとなっている。このボルト 頭部及びその周辺のコンクリートの温度とコンクリート内部を伝達 する応力の関係が加熱下のアンカーボルトの引抜き耐力を決定する 要因の一つと考えられる。

\section{2 温度の上昇速度の違いに関する検討}

破壊時のボルト頭部温度と引抜き耐力の関係を図12に示す。異な る加熱速度で加熱した場合の結果を比較すると，ボルト頭部温度が $160^{\circ} \mathrm{C}$ までの範囲では, 破壊時のボルト頭部温度と引抜き耐力の関係 はほぼ一致している。

加熱時温度の上昇速度が速い場合，試験体表面の温度は非常に高 くなっているが,それは試験体加熱面のごく表層部に限られており，
試験体内部の温度差が大きい。一方，上昇速度が迤い場合には試験 体内部の温度差は小さくなっている。つまり，ボルト頭部温度に着 目すると，遅い加熱速度の場合，速い加熱速度の場合のボルト頭部 温度に達した時，表面温度は速い加熱速度の時より低くなる。

しかし，ボルト頭部温度が $160^{\circ} \mathrm{C}$ を超えると，破壊時のボルト頭部 温度と引抜き耐力の関係は一致していない。加熱速度が速い時アン カーボルトの引抜き耐力は $20 \%$ まで低下したのに対して，加熱速度 が遅い場合の引抜き耐力の低下は $50 \%$ 程度であった。表面温度 $250{ }^{\circ} \mathrm{C}$

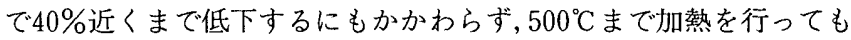
それ以下には耐力は低下しない。アンカーボルトに常温での引抜き

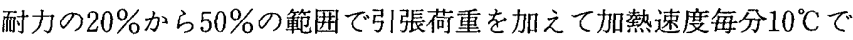
加熱試験を行った試験体は埋め込み深さ $3 \mathrm{~cm}$ は 8 体, 埋め込み媣さ $5 \mathrm{~cm}$ は 5 体あり，埋め込み深さ $5 \mathrm{~cm}$ の試験体 1 体を除いて全ての試 験体が加熱中に破壊した。同様の引張荷重の範囲で加熱速度毎分 $0.75^{\circ} \mathrm{C}$ の加熱試験を行った結果, 埋め込み梁さ $3 \mathrm{~cm}$ は 7 体中 4 体 が，埋め込み梁さ $5 \mathrm{~cm}$ は 6 体中 3 体が引抜き破壊しなかった。

加熱速度が速い場合には，急激な加熱によってコンクリート表面 に爆裂が起こることがある。爆裂は急激な温度上昇, 熱応力, 含水 量などが原因に挙げられるが，特に爆裂の主因は水蒸気圧の大きさ によると考えられており,これらの条件が複合して爆裂が発生する。 本実験において，試験体は試験当日まで湿潤䅅生としており，加熱 速度毎分 $10^{\circ} \mathrm{C} て ゙$ 加熱を行った試験体が破壊した際大きな爆発音を 伴った。また，破壊時加熱されたコンクリート表面全体が粉砕し飛 び散ったことから, 加熱速度が速い場合, 加熱面であるアンカーボ ルトを埋め込んだコンクリート表面に爆裂が生じたと推測できる。 引張荷重が小さい場合，このコンクリート表面の爆裂が引抜き破壊 を誘発したと考えられる。

\section{3 加熱後の引抜き耐力の検討}

加熱した後冷却を行った場合アンカーボルトの埋め込み深さ $3 \mathrm{~cm}$ 及び $5 \mathrm{~cm}$ の残存引抜き耐力と加熱温度の関係はほぼ一致した。 コンクリートを加熱及び冷却することで，コンクリート内部に熱忘 カが発生する。本実験では加熱をアンカーボルトを埋め込んだコン クリート表面から行い, アンカーボルトに引張荷重が加わった際に 力が伝達するコンクリート部分は特に温度変化が激しかった。加熱 時, 冷却時のコンクリート内部に生じる温度差が大きいほど熱応力 が大きくなり，熱ひずみも増大する。そのため加熱温度が高いほど， 
また加熱速度が速いほど加熱後の引抜き耐力の低下が大きくなった と考えられる。

\section{5. 結}

本研究では, アンカーボルトの埋め込み梁さを $3 \mathrm{~cm}$ および $5 \mathrm{~cm}$ として高温を受けるコンクリートに埋め込んだアンカーボルトの引 抜き試験を行った。加熱は試験体表面温度上昇速度を毎分 $10^{\circ} \mathrm{C}$ 及び $0.75^{\circ} \mathrm{C}$ と, 常温から $500^{\circ} \mathrm{C}$ までの範囲で行った。本実験結果より得 た知見を以下に示す。

- 加熱時の試験体表面温度上昇速度が同じ場合, 埋め込み樑さ $3 \mathrm{~cm}$ 及び $5 \mathrm{~cm}$ のアンカーボルトの引抜き耐力低下率と表面温度の関 係はほぼ一致した。

・ボルト頭部温度が常温から $160^{\circ} \mathrm{C}$ までの範囲では, 試験体表面温度 上昇速度が異なる加熱下でアンカーボルトの引抜き耐力の低下率 とボルト頭部温度の関係は一致し，引抜き耐力は $40 \%$ まで低下し た。しかしボルト頭部温度が $160^{\circ} \mathrm{C}$ を超えると, 加熱速度毎分 $10^{\circ} \mathrm{C}$ の場合引抜き耐力が $20 \%$ まで低下したが, 加熱速度毎分 $0.75^{\circ} \mathrm{C} の$ 場合は本実験の加熱条件下では引抜き耐力は $40 \%$ より低下するこ とはなかった。加熱中のアンカーボルトの引抜き耐力をボルト頭 部温度で全ての領域を評価できるとは限らないといえる。

・ $500^{\circ} \mathrm{C}$ までの加熱後常温に冷却したアンカーボルトの引抜き耐力 は，最大 $50 \%$ まで低下する。加熱・冷却時コンクリートに生じる 熱Uずみによっで引抜き耐力が低下すると考えられる。

\section{参考文献}

1) 古村福次郎：高温度におけるコンクリート力学的性質に関する研究(その 1），日本建築学会論文報告集，No. $172 ，$ pp. $11 \sim 18$, 昭和 45 年 6 月
2) 古村福次郎：高温度におけるコンクリート力学的性質に関する研究(その 2 ）, 日本建築学会論文報告集, No. 173, pp. 17 24, 昭和45年 6 月

3）古村福次郎：高温度におけるコンクリート力学的性質に関する研究(その $3)$, 日本建築学会論文報告集, No. 174, pp.1 7, 昭和 45 年 6 月

4）二瀬賢一, 長尾党博：高温加熱を受けた高強度コンクリートの力学的性質 に関する実験的研究，日本建築学会構造系論文集，No. 541，pp.23～30, 2001 年 3 月

5）安部武雄, 古村福次郎, 戸祭邦之, 黒羽健嗣, 小久保勲：高温度における 高強度コンクリートの力学的特性に関する基礎的研究, 日本建築学会構造 系論文集, No. 515, pp.163 168，1999年 1 月

6）宮本圭一, 大内富夫, 安部武雄, 上杉英樹：高温度における高強度コンク リートの力学的特性, 日本建築学会大会学術講演梗概集 A-2, pp.79 - 80, 2000 年 9 月

7）長尾覚博, 中根，淳：高温を受けるコンクリート部材の水分移動と圧力形 成に関する模型実験, 日本建築学会構造系論文集, No. 452, pp.1 10, 1993 年 10 月

8）長尾覚博, 中根 淳：高温履歴を受けるコンクリートの物性に関する実験 的研究, 日本建築学会構造系論文集, No. 457, pp.1 10, 1994年 3 月

9）長尾覚博, 丹羽博則, 汇戸宏彰, 川地 武：火災時における高強度コンク リートの爆裂に関する一考察, 日本建築学会大会学術講演梗概集 A-2, pp. $41 \sim 44,1998$ 年 9 月

10）有政 紘, 寺井俊夫：骨材およびコンクリートの加熱による哑裂，日本建 築学会大会学術講演梗概集 A-2,pp.77 78,2000年 9 月

11）瀧口克已,橋本 純：熱を受けるコンクリート埋め込みボルトの引抜き耐 力に関する基礎的研究, 日本建築学会構造系論文集, No. 563, pp. $131 \sim 137,2003$ 年 1 月

12）日本建築学会：各種合成構造設計指針・同解説，1985年 2 月

13) Eligehausen, R., and Balogh, T.; Behavior of Fasteners Loaded in Tension in Cracked Reinforced Concrete, ACI Structural Journal, Vol. 92, No. 3, pp.365-379, 1995

14) ACI Committee 349 ; Proposed Addition to Code Requirements for Nuclear Safety Related Concrete Structures (ACI 349-79), ACI Proceedings V.75, No.8, pp.329-335, AUGUST 1978

（2003年 2 月 10 日原稿受理，2003年 3 月 31 日採用決定） 